\title{
Caracterization of phenolic composition of altitude tropical wines in the Brazilian Northeast
}

\author{
Antonio Mendes de Souza Nascimento ${ }^{1}$, Joyce Fagundes de Souza ${ }^{1}$, Ayrlan Oliveira Costa ${ }^{2}$, Sabrina de Freitas Santos ${ }^{1}$, \\ Gildeilza Gomes Silva ${ }^{1}$, and Giuliano Elias Pereira ${ }^{3, a}$ \\ ${ }^{1}$ Master Student, University of Bahia Estate, zip code 48900-000, Juazeiro - BA, Brazil \\ ${ }^{2}$ Enology Laboratory, Embrapa Semiarid, zip code 56302-970, Petrolina - PE, Brazil \\ ${ }^{3}$ Enology Laboratory, Embrapa Grape \& Wine/Tropical Semiarid, zip code 56302-970, PO Box 23, Petrolina, PE, Brazil
}

\begin{abstract}
The main goal of the study was to evaluate the phenolic composition of red wines from grapes cultivated in a tropical of altitud región at $1,100 \mathrm{~m}$, in the Northeast of Brazil, called Chapada Diamantina, in Morro do Chapéu city. The región is located in Bahia Estate at $11^{\circ} 33^{\prime} 11^{\prime \prime} \mathrm{S}$ and $41^{\circ} 09^{\prime} 27^{\prime \prime} \mathrm{W}$. Vineyard was planted in 2011 in randomized blocks, spaced $2.5 \mathrm{~m}$ between rows and $1 \mathrm{~m}$ between plants. Vines were grafted onto Paulsen 1103 rootstock and irrigated by drip. Pinot Noir, Cabernet Franc, Malbec and Cabernet Sauvignon (Vitis vinifera L.) cultivars were vinified separately, in the Laboratory of Enology at Embrapa in Petrolina, Pernambuco Estate, Brazil. Means evaluated for color intensity $(420 \mathrm{~nm}+520 \mathrm{~nm}+620 \mathrm{~nm})$, total anthocyanins (by different $\mathrm{pH}$ ), total polyphenol index (at $280 \mathrm{~nm}$ ), total phenolics (Folin-Ciocalteau) and antioxidante capacity (DPPH) were compared by Tukey testa t $5 \%$ probability. Wines showed different phenolic composition, and can be used to elaborate different quality wines.
\end{abstract}

\section{Introduction}

The vitiviniculture potential of a determined region is obtained by many factors, as climate conditions (temperature, pluviosity and luminosity), soil characteristics (depht, mineral, physical and chemical composition), and human choices (rootstocks, varieties, harvest date, for example), changing the grape and wine composition and typicality [1].

However, vine cultivation in regions outside traditional winegrowing zones is possible due to the development of new technologies, as vine management, irrigation, nutrition, and tests with variety adaptation for each region, as well as for particular enological winemaking. Thes characteristics can influence phenolic composition of the wines, in particular for organoleptic sensations, as color, astringency and bitterness [2-4].

Diversity of the factors cited above can influence grapes and its enological potential, in flavors and in colors, linked to the phenolic profile of the wines [5].

In this contexte, the aim of this work was to evaluate the phenolic composition of red wines elaborated from grapes cultivated in a new winegrowing region, in the Northeast of Brazil.

\section{Material and methods}

Vineyard was installed in Morro do Chapéu - Bahia Estate, at $380 \mathrm{~km}$ from Petrolina. Region is located in a tropical of altitude climate, at 1,100 m, in Morro do Chapéu, Chapada Diamantina, Bahia Estate, at $11^{\circ} 33^{\prime} 11^{\prime \prime}$ South of latitude and $41^{\circ} 09^{\prime} 27^{\prime \prime}$ West of longitude [6]. Vines were planted in January 2011, in an observation unity, to evaluate variety adaptation to the local edapho-climatic conditions.

\footnotetext{
${ }^{a}$ Corresponding author: giuliano.pereira@embrapa.br
}

The observation unity was impanted in a ramdomized block, where each variety is a block, with three replicates, and each one with 30 plants spaced of 2.5 between rows and $1.0 \mathrm{~m}$ between vines, all varieties were grafted onto Paulsen 1103 rootstock, trellising in espalier-double cordon downward and irrigated by drip.

In this study, grapes were harvested in September 2014, being harvest date decided individually for each cultivar, according to the enological potential of each one, to elabored fine quality red wines, taking in account total soluble sugars ( $\left.{ }^{\circ} \mathrm{Brix}\right)$, total acidity ( $\mathrm{g} \mathrm{L}^{-1}$ of tartaric acid) and phenolic tasting of berries.

Pinot Noir, Cabernet Franc, Malbec and Cabernet Sauvignon (Vitis vinifera L.) grapes were harvested at morning and sent immediatelly to Petrolina and Embrapa, in a refrigerated truck at $16^{\circ} \mathrm{C}$. Wines were elaborated according to traditional red winemaking with controlled temperature $\left(25^{\circ} \mathrm{C}\right.$ for alcoholic and $18^{\circ} \mathrm{C}$ for malolactic fermentations) and using sulphur dioxide to prevent oxidation [7]. After fermentations, wines were stabilized at $0^{\circ}$ for 30 days, then were bottled and analysed 30 days after bottling. It was determined color intensity $(420 \mathrm{~nm}+520 \mathrm{~nm}+620 \mathrm{~nm})$ [8], total anthocyanins (by different $\mathrm{pH}$ ) [9], total polyphenol index (at $280 \mathrm{~nm}$ ) [10], total phenolics (Folin-Ciocalteau) [11], and antioxidante capacity (DPPH) [11], and results obtained were compared by Tukey testa at $5 \%$ probability.

\section{Results and discussion}

Results of wines analysed are presented in Table 1.

According to the color intensity, values changed from 3.35 (Pinot Noir) to 12.40 (Malbec). Even showing intermediate values, Cabernet Sauvignon presented the

(C) The Authors, published by EDP Sciences. This is an Open Access article distributed under the terms of the Creative Commons Attribution License 4.0 (http://creativecommons.org/licenses/by/4.0/). 
Table 1. Chemical analysis of the phenolic compounds determined in red wines elaborated from Pinot Noir (PN), Cabernet Franc (CF), Malbec (MA) and Cabernet Sauvignon (CS) grapes, cultivated in Morro do Chapéu city, Chapada Diamantina - Bahia Estate, in the Northeast of Brazil, harvested in September 2014.

\begin{tabular}{|c|c|c|c|c|}
\hline & \multicolumn{4}{|c|}{ Wines evaluated } \\
\hline Parameters & $\mathrm{PN}$ & $\mathrm{CF}$ & MA & $\mathrm{CS}$ \\
\hline $\begin{array}{l}\text { Color } \\
\text { intensity }\end{array}$ & $3.35 \mathrm{~d}$ & $7.87 \mathrm{c}$ & $12.40 \mathrm{a}$ & $8.50 \mathrm{~b}$ \\
\hline $\begin{array}{l}\text { Anthocyanis } \\
\left(\mathrm{mg} \mathrm{L}^{-1}\right)\end{array}$ & $100.36 \mathrm{~d}$ & $201.81 \mathrm{c}$ & $28.47 \mathrm{a}$ & $260.92 b$ \\
\hline $\begin{array}{l}\text { TPI } \\
(\mathrm{I} 280 \mathrm{~nm})\end{array}$ & $27.00 \mathrm{~d}$ & $41.47 \mathrm{c}$ & $58.23 b$ & $59.33 \mathrm{a}$ \\
\hline $\begin{array}{l}\text { Total } \\
\text { phenolics } \\
\text { (mg galic } \\
\left.\text { acid L }{ }^{-1}\right)\end{array}$ & $1024.21 d$ & $1516.65 \mathrm{c}$ & $2503.69 b$ & 2958.96a \\
\hline $\begin{array}{l}\text { DPPH }(\mathrm{mM} \\
\left.\text { TEAC } \mathrm{L}^{-1}\right)\end{array}$ & $6.71 d$ & $10.68 \mathrm{c}$ & $18.91 b$ & $19.63 \mathrm{a}$ \\
\hline
\end{tabular}

highest values in this work, as compared to the results showed by Freitas [12], with wines from the South of Brazil. As expected, Pinot Noir presented the lowes values as compared to the others [7]. Malbec wines presented the highest values, because winemaking process allowed to macerate grapes few days more than others.

Values found in total monomeric anthocyanins for all four wines presented higher than $100.00 \mathrm{mg} \mathrm{L}^{-1}$, and Malbec wine presented the maximum value found (328.47 $\mathrm{mg} \mathrm{L}^{-1}$ ). According to total polyphenol index (TPI), values ranged from 27.00 (Pinot Noir) to 59.33 (Cabernet Sauvignon). For total phenolics, presented in $\mathrm{mg}$ of galic acid per liter of wine (mg galic acid $\mathrm{L}^{-1}$ ), Cabernet Sauvignon (CS) wine presented the highest values $\left(2958.96 \mathrm{mg} \mathrm{EAG} \mathrm{L}^{-1}\right)$, more concentrated as compared with results showed by $\mathrm{Li}$ et al. (2009) [13], evaluating CS in China.

Antioxidant capacity is strongly linked to the phenolic content $[5,14,15]$. This activity is attributed mainly to resveratrol [16], vitamine $C$ [17], and to the anthocyanins content [18]. In general it representes the bioactive capacity of wine components. Results found in this work presented lower antioxidant capacity $\left(\mathrm{mM} \mathrm{TEAC} \mathrm{L}^{-1}\right)$ in samples with lesser values in total phenolics (PN, CF, MA - Table 1), than wines presenting the highest values (CS), in agreement to Abe et al. (2007) [5], that observed the highest antioxidant capacity in wines with high values of total phenolics, as compared to other results, in table wines (Vitis labrusca). Cabernet Sauvignon wine presented the highest values $\left(19.63 \mathrm{mM}\right.$ TEAC $\left.\mathrm{L}^{-1}\right)$, and Pinot Noir

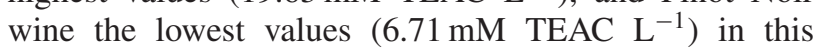
study.

Wines presented different enological potential, and could be indicated, for example, for different wine types. Pinot Noir and Cabernet Franc wines could be used for young wines at this moment, while Malbec and Cabernet Sauvignon wines could be used for guard wines. But vines are very young and other works need to be carried out, to evaluate variety adaptation to this new winegrowing region, in the Chapada Diamantina. Another practices that could be used is the blend beween different sold as varietal or blend wines.

\section{Conclusion}

Wines in this study presented different enological potential of phenolic profile. All wines presented interesting phenolic contentes, someones most indicated for young and others most indicated for red wines.

Cabernet Sauvignon and Malbec presented the highest values of anthocyanins, color intensity, total phenolic index, total phenolics and antioxidante activity, as compared to Pinot Noir and Cabernet Franc wines.

\section{Referencias}

[1] J. Tonieto, A. Carbonneau, IX Congres. Bras. de Vit. e Enol. 1999. ed. 75-90 (1999)

[2] G. E. Pereira, J. O. Santos, C. C Guerra, L. A. Alves, Vllème Congrès International des Terroirs Viticoles (2008)

[3] M. De A. Regina, E. L. Do Carmo, A. R. Fonseca, E. Purgatto, T. M. Shiga, F. M. Lajolo, A. P. Ribeiro, R. V. Da Mota, Rev. Bras. Frutic., 32 (1), 143-150 (2010)

[4] G. E. Pereira, A. J. B. Araújo, J. Santos, R. Vanderlinde, L. L. A. Lima, Acta Horticulturae, (910), 135-140 (2011)

[5] L. T. Abe, R. V. da Mota, F. M. Lajolo, M. I. Genovese, Ciênc. Tecnol. Aliment. 27(2), 394-400 (2007)

[6] A. P. Torres, J. B. Oliveira, L. Berron, J. Vaz, O. Gomes, T. R. Menezes, L. R. V. Morais, P. F. Silva, A. C. T. Biasoto, G. E. Pereira, Ciên. Técn. Vitivin. 28, 260-265 (2013)

[7] E. Peynaud, Editora Dunod, Paris, 341p. (1997)

[8] Y. Glories, Conn. Vigne Vin. 18 (4), 253-271 (1984)

[9] J. Lee, R. W. Durst, R. E, Wrolstad. Journ. of AOAC International, 88 (5), 1269-1278 (2005)

[10] V. Cheynier, M. Moutounet, P. Sarni-Manchado. Ediciones Mundi-Prensa. 1.ed, 783p. (2000)

[11] M. S. Lima, I. S. V. Silani, I. M. Toaldo, L. C. Corrêa, A. C. T. Biasoto, G. E. Pereira, M. T. BordignonLuiz, J. L. Ninow, Food Chemistry, 161, 94-103 (2014)

[12] D. M. De Freitas, UFSM, Tese, 56 p. (2006)

[13] H. Li, X. Wang, Y. Li, P. Li, H. Wang, Food Chemistry, 112, 454-460 (2009)

[14] V. Katalinic, M. Milos, D. Modun, I. Music, B. Boban, Food Chemistry.86, 593-600 (2003)

[15] W. C. Gallice, I. Messerschmidt, P. P. Zamora, Química Nova, 34 (3), 397-403 (2011)

[16] M. Arenhart, A. O. Fogaça, B. B. Oliveira, In: Conbran, Anais (2012)

[17] J. Sun, J. of Agri. and Food Chem. 50 (25), $7449-7454$ (2002)

[18] N. F. S. Vaccari, M. C. H. Soccol, G. M. Ide, Rev. de Ciênc. Agoveter. 8 (1), 71-83 (2009) 